\title{
Development of hypopharyngeal glands in adult honey bees fed with a Bt toxin, a biotin-binding protein and a protease inhibitor
}

\author{
Louise A. MALONE ${ }^{\text {a*, Jacqui H. TODD }}{ }^{\mathrm{a}}$, Elisabeth P.J. BuRGESS ${ }^{\mathrm{a}}$, \\ John T. CHRISTELLER ${ }^{\mathrm{b}}$ \\ ${ }^{\text {a }}$ Horticulture and Food Research Institute of New Zealand Limited, Mt Albert Research Centre, \\ Private Bag 92169, Auckland, New Zealand \\ b Horticulture and Food Research Institute of New Zealand Limited, Palmerston North Research Centre, \\ Private Bag 11030, Palmerston North, New Zealand
}

(Received 21 November 2003; revised 21 April 2004; accepted 27 April 2004)

\begin{abstract}
To investigate potential impacts of insecticidal transgene products on hypopharyngeal gland development, newly-emerged adult honey bees were kept in cages and fed for ten days with a pollen-food to which one of the following proteins had been added at concentrations equivalent to pollen expressing $1.25 \%$ (of total protein) aprotinin, $11.2 \mu \mathrm{M}$ avidin or $0.3 \%$ Cry1Ba protein. Control bees were fed pollenfood without additive, with casein added, or pollen-candy. None of the treatments significantly affected bee survival, or the mean diameters of gland acini, gland mass or protein content on Days 1, 4, 8 or 10. Bees consumed significantly more of the pollen-candy than the other foods. Assays showed no evidence of aprotinin, avidin or Cry1Ba in the glands of bees fed with these proteins. Thus effects of these transgene products on gland development are unlikely, but field trials using transgenic plants are required for a full assessment.
\end{abstract}

Apis mellifera / hypopharyngeal gland / insecticidal transgenic plant protein / laboratory assay

\section{INTRODUCTION}

Toxicity tests with purified transgene products are often the first step in assessing risks to honey bees from transgenic crop plants. The results of many of these tests have now been published (reviewed by Malone and PhamDelègue, 2001), particularly for insecticidal proteins, with very few showing negative effects on bee survival.

Bt toxins that target lepidopteran pests (Cry1Ac, Cry1 Ab, Cry1Ba and Cry9C) or coleopteran pests (Cry3A and Cry3B) have been fed to adult and/or larval honey bees with no detrimental effects (Anon, 2000; Arpaia, 1996; Malone et al., 1999, 2001; Sims, 1995). A semifield study with transgenic Cry1 Ab-expressing corn showed no adverse effects on honey bee colonies (Schur et al., 2000, reported in Anon, 2000). Experiments in which honey bee larvae in colonies were fed with pollen from Cry $1 \mathrm{Ab}$ and Cry $1 \mathrm{~F}$-expressing corn (active against lepidopteran pests) have also revealed no significant impacts attributable to the transgenic pollen (Hanley et al., 2003).

Biotin-binding proteins (BBPs) are a lesserknown group of insecticidal proteins, recently expressed in transgenic plants (Hood et al., 1997; Murray et al., 2002). BBPs have activity against a broad range of insects. Leaf-feeding lepidopteran larvae were susceptible to BBPs expressed in transgenic tobacco and apple plants (Burgess et al., 2002a; Markwick et al., 2003)

\footnotetext{
* Corresponding author: LMalone@ hortresearch.co.nz
} 
and grain-feeding coleopteran and lepidopteran storage pests were susceptible to a BBP expressed in maize kernels (Kramer et al., 2000). Orthopteran activity was demonstrated using BBPpainted leaf material (Malone et al., 2002a) and artificial diet assays have shown effects on dipterans (Bruins et al., 1991) and mites (Levinson et al., 1992). Honey bee adults and larvae fed with avidin at concentrations exceeding realistic exposure levels were unaffected by this BBP (Malone et al., 2002b).

Protease inhibitors (PIs) are another group of insecticidal proteins expressed in several transgenic plant species, but not yet commercialised. PI activity has been demonstrated against Coleoptera, Lepidoptera and Orthoptera (Leplé et al., 1995; Graham et al., 1997; Heath et al., 1997; Christeller et al., 2002). Some purified PIs have been shown to reduce the longevity of both adult and larval honey bees when fed to them at high doses. For example, honey bee larvae fed Kunitz soybean trypsin inhibitor (SBTI) in an artificial diet (1\% w: w of total protein) had delayed development and increased mortality compared with those on control diet (Brødsgaard et al., 2003). Since pollen is only a minor component of the natural diet of larval bees (Babendreier et al., 2004), this concentration is likely to be greater than that which bee larvae would be exposed to in transgenic crops. Adult honey bees fed with SBTI and other PIs at concentrations about four times the effective leaf expression levels for such proteins also have reduced longevity (Malone et al., 1995, 1998, 2001; Burgess et al., 1996; Jouanin et al., 1998). Behavioural changes have also been observed in some bees fed with PIs. Cowpea trypsin inhibitor added to the reward syrup in a conditioned proboscis extension assay reduced the ability of adult honey bees to learn this response (Picard-Nizou et al., 1997). Honey bee adults fed at emergence with aprotinin (a trypsin inhibitor) and returned to their hives were observed flying significantly sooner than those fed with control food (Malone et al., 2001). There have been few published attempts to measure expression of PIs in pollen or nectar of transgenic plants, and none have yet detected these proteins in these plant parts (Bonadé Bottino et al., 1998; Jouanin et al., 1998). This suggests that honey bee exposure to PIs may be low in a field situation. However, changes in digestive protease activities in the guts of adult honey bees fed with even low concentrations of PIs raise the possibility of sub-lethal impacts on these non-target insects (Burgess et al., 1996; Malone et al., 1998; Pham-Delègue et al., 2000).

Because social interactions are important for honey bee colony survival, compounds with sub-lethal impacts on bee physiology and/or behaviour could affect the health of the entire colony. For example, the hypopharyngeal glands of adult bees can secrete jelly for feeding to bee larvae only if the adult receives sufficient protein during the first few days after emergence for the glands to complete development and become functional (Crailsheim and Stolberg, 1989). Compounds interfering with gland development in newly-emerged adult bees might therefore affect the survival of larvae in the colony, even if adult survival itself is not affected.

Additionally, Brødsgaard et al. (2003) have suggested that some proteins, such as PIs, expressed by transgenic plants and ingested by adult bees may pass intact through the gut epithelium, be transported to the glands, secreted with the jelly and thus fed to larvae. Such a mechanism would increase the potential exposure of bee larvae to transgene products. Many studies with other insects have shown the uptake of proteins from the diet into the haemolymph (e.g. immunoglobulin G: Hatfield, 1988; horseradish peroxidase: Fishman and Zlotkin, 1984), probably intercellularly through leaky epithelial cell gap junctions (Billingsley and Lehane, 1996). Vaughan et al. (1990) calculated that $0.5 \%$ of ingested immunoglobulin passed into the haemolymph in mosquitoes. Uptake of ingested protein from the haemolymph by the salivary glands and Malpighian tubules (e.g. horseradish peroxidase: Colebatch, 1999) has also been demonstrated qualitatively. Similar studies on protein uptake in honey bees have not yet been conducted.

To investigate potential impacts of insecticidal transgene products on hypopharyngeal gland development, we fed aprotinin, avidin and Cry $1 \mathrm{Ba}$ protein to newly-emerged adult honeybees in quantities that were equivalent to their receiving high-expressing pollen from transgenic plants with these genes and measured their glands. We also assessed the protein content of glands and conducted biochemical analyses to detect transgene products in the glands of bees that had been fed with them. 


\section{MATERIALS AND METHODS}

Activated Cry1Ba toxin was obtained from a large-scale fermentation of Bacillus thuringiensis Bt4412, purified and cleaved as described by Simpson et al. (1997) and stored freeze-dried. Purified lyophilised avidin from egg white (Lot 276992) was obtained from the Calbiochem-Novabiochem Corporation (La Jolla, CA 92039) and also stored frozen. Purified aprotinin (Lot WT64111) was obtained from Intergen $\circledast$ Company, Canada/USA and stored at $4{ }^{\circ} \mathrm{C}$.

The entire experiment described below was conducted on three separate occasions (hereafter referred to as "blocks").

Newly emerged Italian race adult honey bees (Apis mellifera L.) were obtained from our apiary at Mt Albert Research Centre, Auckland, New Zealand. These were assigned randomly to wooden, meshsided cages (approximately 30 bees per cage), supplied with water and sugar syrup (60\% w:v sucrose solution) via gravity feeders, and kept in an incubator in darkness at $33{ }^{\circ} \mathrm{C}$. Each cage also contained a disposable, pre-weighed, plastic cup filled with a known mass of pollen-food.

Six types of pollen-food were prepared: three "controls" (1) base recipe (formulation see below), (2) base with $2.5 \mathrm{mg} / \mathrm{g}$ extra casein, and (3) pollencandy, and three with transgene products added (1) base with $0.625 \mathrm{mg} / \mathrm{g}$ Cry1Ba (Bt toxin), (2) base with $0.174 \mathrm{mg} / \mathrm{g}$ avidin, and (3) base with $2.5 \mathrm{mg} / \mathrm{g}$ aprotinin. The base recipe was $29 \mathrm{~g}$ mixed-floral beecollected pollen, $7 \mathrm{~g}$ sodium caseinate, $14 \mathrm{~g}$ brewers yeast, $38 \mathrm{~g}$ sucrose mixed to a paste with $12 \mathrm{~mL}$ water. The pollen-candy was composed of 1 part mixedfloral bee-collected pollen mixed with 2 parts candy (Ambrose, 1992). Each container of food was weighed and replaced daily for the first ten days of the experiment. After that a single container of base food was left in each cage until the end of each block. For the Cry1Ba-food, aliquots of the toxin were kept at $-20{ }^{\circ} \mathrm{C}$ and added to the base food daily to minimise any loss of toxicity; the other foods were made up at the beginning of each block and kept at $4{ }^{\circ} \mathrm{C}$ (since avidin and aprotinin are more stable than Cry1Ba). The total protein content of each food was estimated to be approximately 19\% w:w (based on the manufacturer's figures for the protein content of the yeast, sodium caseinate and additives, and assuming the pollen used was $25 \%$ protein), except for the pollencandy which was about $8 \%$. In each block, each of the six foods was given to three cages (i.e. 18 cages per block). Thus each treatment was delivered to a total of approximately 270 bees.

The concentrations of insecticidal proteins used were chosen to simulate bees receiving pollen expressing $0.3 \%$ Cry $1 \mathrm{Ba}$ (of total protein), 11.2 $\mu \mathrm{M}$ avidin and $1.25 \%$ aprotinin (of total protein). To put this in context, Bt expression levels in pollen of transgenic plants are typically 0.0000044 to $0.0002 \%$ of total protein when the CaMV 35S promoter is used (Anon, 2000; Greenplate, 1997) and 0.002 to $0.04 \%$ when a pollen-specific promoter is used (StanleyHorn et al., 2001; Koziel et al., 1993). Avidin and aprotinin expression in pollen has not yet been measured, but transgenic plants are insecticidal with minimum leaf expression levels of $3 \mu \mathrm{M}$ avidin (Burgess et al., 2002a) and $0.5 \%$ of total protein for aprotinin (Christeller et al., 2002).

The amounts of solid food consumed by the bees in each cage were determined by weighing leftover food from each cage daily until Day 10 (from the beginning of each block). Earlier measurements had shown that evaporation from the food containers was consistent and minor. Consumption of sucrose solution and water was not measured. Previous experiments using the same set-up have shown that each bee consumes approximately $0.032 \mathrm{~mL}$ of sucrose syrup per day (unpublished data). Bee survival was monitored daily until the end of each block. For gland measurements, three bees were removed from each cage on Days 1, 4, 8 and 10. These and about 20 newly-emerged (Day 0) bees from the same hives were stored frozen until each block ended (on Days 38,44 and 44, respectively). Bees were then thawed, decapitated and one of their hypopharyngeal glands removed. Each gland was mounted in a drop of sterile distilled water on a glass slide and examined using phase-contrast microscopy at 100x magnification. The diameters of six acini, selected at random from each gland, were measured using an eyepiece graticule. A pilot study to compare acinus diameters of glands dissected in sterile distilled water or in $0.25 \mathrm{M} \mathrm{NaCl}$ showed no significant size differences attributable to the dissection medium (data not shown).

Additional measurements were made from bees in the third block. Each dissected gland was weighed and assayed for total protein content. Glands from bees fed with transgene products were also assayed for the presence of the product with which they had been fed. Control glands were also assayed for each transgene product.

For biochemical analyses, each gland was homogenised individually in $100 \mu \mathrm{L}$ ice-cold MOPS $50 \mathrm{mM}$, $\mathrm{pH} 7.5$, centrifuged for $5 \mathrm{~min}$ and the supernatant retained for analyses. Protein was measured using the Bradford assay in microtitre plates; $200 \mu \mathrm{L} \mathrm{Brad-}$ fords reagent (BioRad, CA, USA) $(40 \mu \mathrm{L}$ stock diluted 5-fold with water) was mixed with $10 \mu \mathrm{L}$ gland extract (x2) and measured after $10 \mathrm{~min}$ at $600 \mathrm{~nm}$ in tandem with a standard curve of 0-7 $\mu \mathrm{g}$ BSA.

To determine if aprotinin had accumulated in glands, inhibition of its target protease, trypsin, was assayed. Preliminary ELISA tests for aprotinin in glands (method described in Burgess et al., 2002b) 
showed that this method was not sensitive or reliable enough to measure this inhibitor in bee gland tissue. Instead, known quantities of trypsin were added to the gland preparations and resultant trypsin activities in control and aprotinin-fed bees were compared. Ten $\mu \mathrm{L}$ of gland extract was mixed in a black fluorescent microtitre plate with $100 \mu \mathrm{L} 0.1 \mathrm{M}$ tris- $\mathrm{HCl}$, $0.01 \%$ Tween 20 , pH 8.0 and $10 \mu \mathrm{L} 1 \mathrm{mM}$ Z-GlyGly-Arg-AMC (Bachem F AG, Switzerland) in dimethyl sulphoxide. Initial velocities were measured using a SpectroMax Gemini (Applied Biosystems, USA) plate fluorimeter at $380 \mathrm{~nm}$ excitation and $460 \mathrm{~nm}$ emission. A standard curve of bovine trypsin (2-fold serial dilutions from $10 \mathrm{ng}$ ) was run in all extracts tested and used to detect inhibition and to construct a standard curve. The assay set a detection limit for trypsin of $0.5 \mathrm{ng}$ per gland and a detection limit for aprotinin of $0.13 \mathrm{ng}$ per gland.

Accumulation of avidin and Cry1Ba in glands was assayed by ELISA. Supernatants $(25 \mu \mathrm{L} \times 2)$ were incubated with $80 \mu \mathrm{L}$ coating buffer $(30 \mathrm{mM}$ sodium bicarbonate, $120 \mathrm{mM}$ sodium carbonate, $\mathrm{pH}$ 9.6) overnight at $4{ }^{\circ} \mathrm{C}$ in absorptive multiwell plates (Nunc Co., USA). The plates were washed $3 \times$ in PBS (0.025\% Tween 20) (PBST) and incubated in $100 \mu \mathrm{LPBST}, 0.5 \%$ gelatin for $1 \mathrm{~h}$, washed and incubated in primary antibody (1/7500 for anti-avidin, Sigma Co., St Louis, USA and 1/2000 for anti-Cry1Ba in PBST) for $1 \mathrm{~h}$, washed and incubated in goat-antirabbit-alkaline phosphatase (1/5000, Sigma Co.) in PBST for $1 \mathrm{~h}$, washed and initial velocities determined using p-nitrophenol $(0.5 \mathrm{mg} / \mathrm{mL})$ in $0.1 \mathrm{M}$ diethanolamine- $\mathrm{HCl}, 0.5 \mathrm{mM} \mathrm{MgCl}, \mathrm{pH} 9.6$ in a DynaTech MR5000 plate reader at $410 \mathrm{~nm}$. Standard curves using serial dilutions of avidin (from $0.2 \mathrm{ng}$ ) and Cry1Ba (from $1.2 \mathrm{ng}$ ) were processed in parallel. The assays set detection limits of $0.2 \mathrm{ng}$ avidin and 0.8 ng Cry1Ba per gland.

Bee survival was analysed by ANOVA of angular-transformed mean percentages of bees alive on Days 1, 4, 8, 10, 20, 30, 40 and 44. ANOVA was also used to compare mean masses of food consumed per bee per day between Days 0 and 9 and mean acinus diameter of glands. Newly-emerged bees' glands (Day 0) were compared with all of those taken from bees on Days 1, 4, 8 and 10 and then the effects of treatment and day on the size of glands from all the experimental bees were analysed separately. The mean masses of glands taken from bees in the third block on Days 1, 4, 8 and 10 were compared using ANOVA, as were the levels of total protein, trypsin, avidin and Cry $1 \mathrm{Ba}$ in each gland removed on Days 1 and 10 . Trypsin, avidin and Cry $1 \mathrm{Ba}$ measurements from the glands of bees fed with aprotinin, avidin or Cry1Ba, respectively, were also compared with the measurements obtained from control gland preparations.

\section{RESULTS}

\subsection{Survival}

Bee survival was very variable, with significant differences attributable to some treatments on some days within each of the three blocks. No consistent pattern of effects was evident. Within Block 1, significantly more bees were alive on Day 30 after avidin treatment than with candy feeding $(P<0.05)$; the other bees in that block had intermediate survival. Within Block 2, there were also some significant differences among the treatments, but there were no consistent patterns. Block 2 aprotininfed bees had poorer survival than those on casein, avidin or Cry1Ba on Day 30, aprotininfed bees had poorer survival than those on casein on Day 40 and they had poorer survival than those on control food on Day $44(P<0.05)$. In Block 3, bees fed with casein had poorer survival on Day 30 than those on control food $(P<$ $0.05)$, but those on other treatments had intermediate survival on that day. On all other occasions, there were no significant treatment effects. When results from the three blocks were combined, there were no significant treatment effects (Fig. 1). Combined results from Days 40 and 44 are not shown, as they were so variable that the LSDs were larger than some of the mean values.

\subsection{Food consumption}

In each block, bees given pollen-candy consumed significantly more of this food than the others $(P<0.05)$, even though all bees were given food in excess of their needs (Fig. 2). Only on Day 1 were food consumption rates uniform for all treatments.

\subsection{Acinus diameter}

In Blocks 1 and 2, glands from newly-emerged bees had significantly smaller acini than those examined on later days, regardless of the treatment they received $(P<0.05)$. In all blocks, bees across all treatments had significantly smaller acinus diameters on Day 1 than on Days 4 and 8. On Day 10, acinus diameters were intermediate. There were no significant treatment effects on acinus diameter (Fig. 3). 

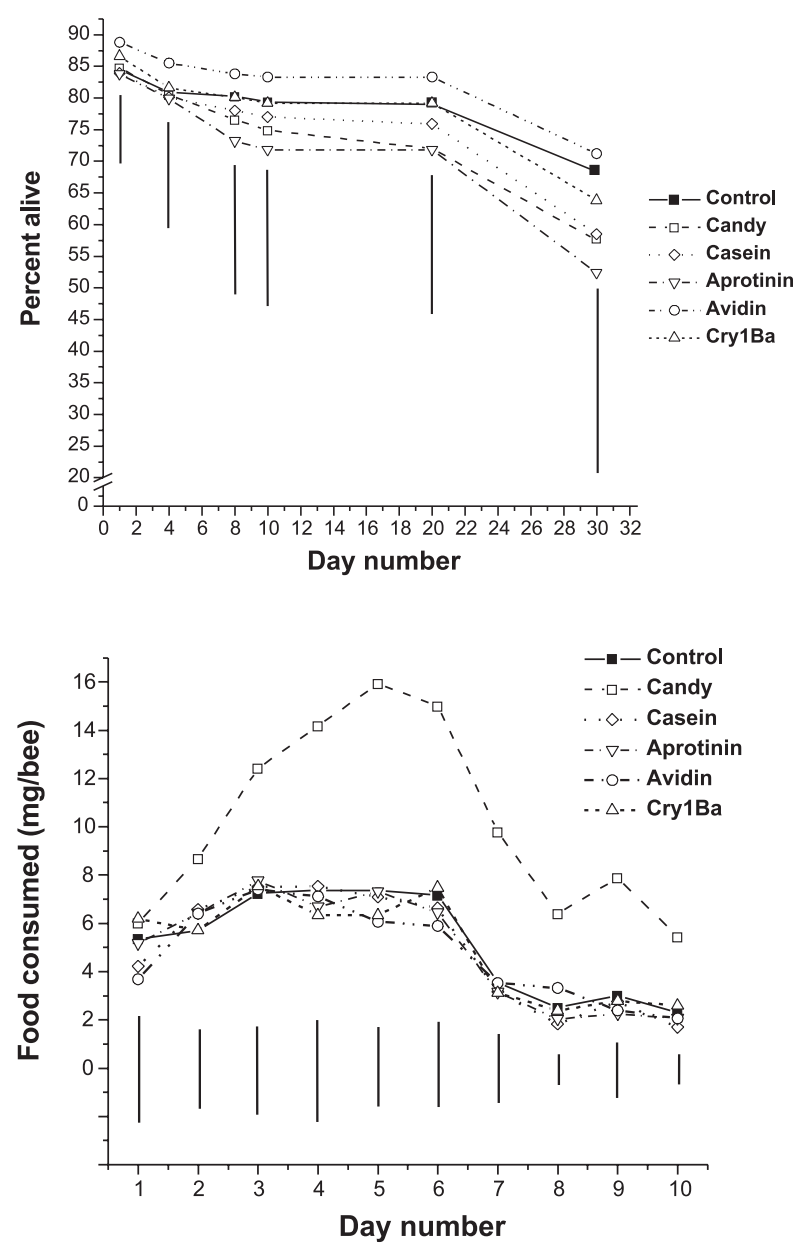

Figure 1. Mean percentage of adult bees surviving after feeding for 10 days on six different foods, three with transgene products added $(625 \mu \mathrm{g} / \mathrm{g}$ Cry $1 \mathrm{Ba}$, $174 \mu \mathrm{g} / \mathrm{g}$ avidin and $2.5 \mathrm{mg} / \mathrm{g}$ aprotinin) and three without (control = base food, casein $=$ base food plus $2.5 \mathrm{mg} / \mathrm{g}$ extra casein, candy $=$ pollen/candy mixture) (three blocks of 90 bees per treatment combined). Vertical bars represent Tukey's LSD (0.05).

Figure 2. Mean consumption by adult bees of six different foods, three with transgene products added $(625 \mu \mathrm{g} / \mathrm{g}$ Cry $1 \mathrm{Ba}, 174 \mu \mathrm{g} /$ $\mathrm{g}$ avidin and $2.5 \mathrm{mg} / \mathrm{g}$ aprotinin) and three without (control $=$ base food, casein $=$ base food plus $2.5 \mathrm{mg} / \mathrm{g}$ extra casein, candy = pollen/candy mixture) (three blocks of 90 bees per treatment combined). Vertical bars represent Tukey's LSD (0.05).

\subsection{Gland mass}

On Day 1, the glands of bees fed with control or aprotinin foods were significantly heavier than those given the other foods $(P<0.05)$ (Fig. 4). Otherwise, there were no significant treatment effects on gland mass.

\subsection{Protein, trypsin, avidin and Cry1Ba content of glands}

The mean total protein content of hypopharyngeal glands taken on Days 1 and 10 from bees subjected to all six treatments are shown in Table I. There were no significant differences among them.

Trypsin inhibition (an indication of the presence of aprotinin), avidin and Cry $1 \mathrm{Ba}$ were all undetectable in the samples examined, suggesting that none of the transgene products ingested by bees in this experiment had been transported to their hypopharyngeal glands.

\section{DISCUSSION}

Different pollen-foods, some with transgene products added, had no effect on the survival of caged adult bees for the duration of this experiment. For avidin and Cry1Ba, this accords with earlier findings (Malone et al., 2001, 2002b). However, bees fed with the same concentration of aprotinin for only seven days then returned to their hives began flying and died sooner than control or Cry1Ba-fed bees in an earlier study 


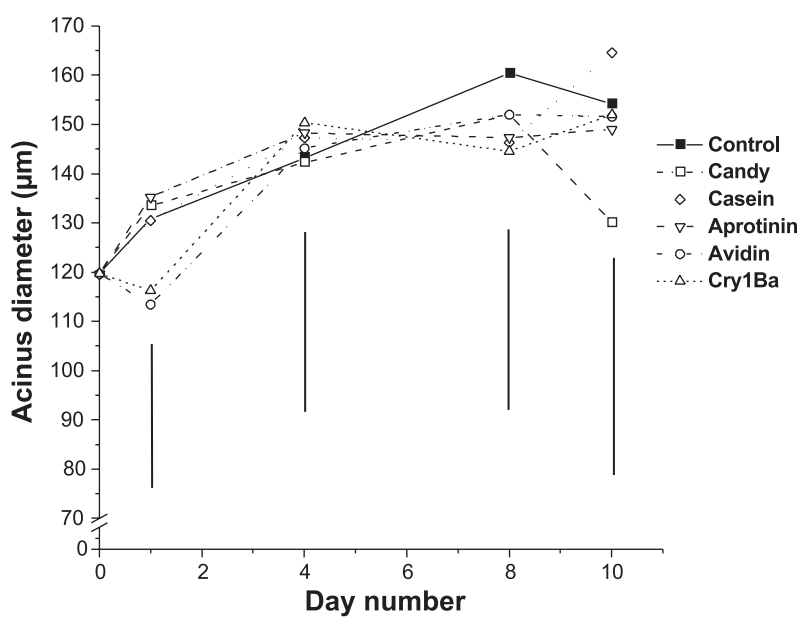

Figure 3. Mean diameters of acini of hypopharyngeal glands of bees fed with six different foods, three with transgene products added $(625 \mu \mathrm{g} / \mathrm{g}$ Cry $1 \mathrm{Ba}, 174 \mu \mathrm{g} / \mathrm{g}$ avidin and $2.5 \mathrm{mg} / \mathrm{g}$ aprotinin) and three without (control = base food, casein $=$ base food plus $2.5 \mathrm{mg} / \mathrm{g}$ extra casein, candy $=$ pollen/candy mixture) (three blocks of 90 bees per treatment combined). Vertical bars represent Tukey's LSD (0.05).

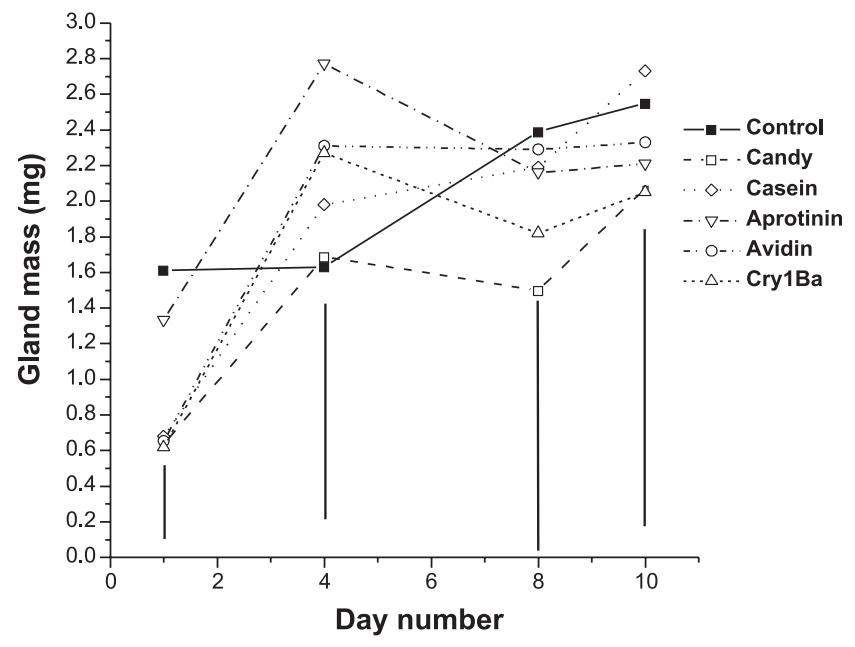

Figure 4. Mean masses of hypopharyngeal glands dissected from bees fed with six different foods, three with transgene products added ( $625 \mu \mathrm{g} / \mathrm{g}$ Cry $1 \mathrm{Ba}, 174 \mu \mathrm{g} / \mathrm{g}$ avidin and $2.5 \mathrm{mg} / \mathrm{g}$ aprotinin) and three without (control $=$ base food, casein $=$ base food plus $2.5 \mathrm{mg} / \mathrm{g}$ extra casein, candy $=$ pollen $/$ candy mixture $)$ (one block of 30 bees per treatment). Vertical bars represent Tukey's LSD (0.05).

(Malone et al., 2001). This suggests that conditions in cages favoured bee survival compared with those in the hive, an effect which may be connected with the lack of opportunity for flight in this situation.

None of the transgene product additives affected food consumption by the bees. This accords with earlier studies in which bees fed readily on protease inhibitors and Bt toxins (Malone et al., 1999) and avidin (Malone et al., 2002b). In the present experiment, bees ate more of the pollen-candy than the other foods, which contained casein and yeast and were estimated to have more than twice the total protein 
Table I. Mean total protein content ( $\mu \mathrm{g}$ per gland) of hypopharyngeal glands taken from bees fed six different foods, three with transgene products added $(625 \mu \mathrm{g} / \mathrm{g}$ Cry $1 \mathrm{Ba}, 174 \mu \mathrm{g} / \mathrm{g}$ avidin and $2.5 \mathrm{mg} / \mathrm{g}$ aprotinin) and three without (control = base food, casein = base food plus $2.5 \mathrm{mg} / \mathrm{g}$ extra casein, candy = pollen/candy mixture) (one block of 30 bees per treatment).

\begin{tabular}{lccccccc}
\hline Treatment: & Control & Candy & Casein & Aprotinin & Avidin & Cry1Ba & LSD (0.05) \\
\hline Day 1 & 12.3 & 13.3 & 16.0 & 13.0 & 15.3 & 13.8 & 6.88 \\
Day 10 & 30.8 & 45.7 & 57.8 & 27.9 & 49.4 & 37.5 & 55.29 \\
\hline
\end{tabular}

content of the pollen-candy food. The bees may have eaten more of the protein-poor candy food to compensate for this. An alternative explanation is that the higher sugar concentration of the pollen-candy than the other foods may have made it more attractive or palatable to the bees.

Bees kept in cages can undergo some hypopharyngeal gland development, provided that they are supplied with protein, but the glands do not develop to the extent that they may in bees kept in colonies (Crailsheim and Stolberg, 1989; Crailsheim et al., 1993; Lass and Crailsheim, 1996). In the hive, the presence of larval brood, larval feeding activity (Huang and Otis, 1989) and the presence of older adult bees (Suzuki, 1988; Naiem et al., 1999) have been shown, in addition to protein consumption, to promote gland development. Attempts (in pilot experiments prior to the present study) to feed the bees pollen-food in the laboratory for a short period and then return them to their hives for later retrieval and gland measurement failed due to rejection by other members of the colonies (unpublished data). Furthermore, keeping newly-emerged bees in cages with a section of brood comb or with older bees as companions did not result in larger glands (unpublished data). In spite of this, measurable gland development was observed in caged bees using the methods described here and the various treatments administered did not significantly alter this. Measurements of acinus diameter, gland mass and protein content of the glands suggested that aprotinin, avidin and Cry $1 \mathrm{Ba}$, if present in transgenic pollen at the concentrations tested here, are extremely unlikely to have a marked effect on hypopharyngeal gland development. For the biotin-binding protein and the Bt toxin, this is in accord with earlier reports of no impacts on bees (Sims, 1995; Arpaia, 1996; Malone et al., 1999, 2001, 2002b).

In contrast, bee toxicity has been observed when high concentrations of protease inhibi- tors are fed (Burgess et al., 1996; Sandoz, 1996; Malone et al., 1995, 1998, 2001; Jouanin et al., 1998). Furthermore, an earlier study in which newly-emerged bees were fed for seven days with the same aprotinin-food as that used here and then returned to their colonies, showed that such bees began flying and died sooner than the controls (Malone et al., 2001).

It is highly likely that in a hive (e.g. in the presence of brood and greater numbers of bees), there is a greater turnover of protein and a higher rate of protein synthesis in worker bees' glands than in caged bees in the laboratory. There are limitations to the usefulness of laboratory-based assays for honey bees, since social realism is inevitably lost when bees are placed in cages. Laboratory tests may provide helpful suggestions for effects to look for, but field trials will always be a necessary step in the assessment of non-target effects of any transgenic crop.

We found no evidence, within the detection limits of the assays, that aprotinin, avidin or Cry1Ba had passed intact through the bee gut epithelium and accumulated into the hypopharyngeal glands, as was suggested by Brødsgaard et al. (2003). This indicates that these proteins are extremely unlikely to be passed on to bee larvae via secreted jelly. Direct feeding of pollen to larvae is by far the most likely route for their exposure to transgene products, if they are expressed in that tissue.

Clearly, the full significance of transgenic plants expressing aprotinin, avidin or Cry $1 \mathrm{Ba}$ for bee colony health will be best determined in field trials. Laboratory experiments to date suggest that negative effects, if they occur at all, are likely to be extremely subtle.

\section{ACKNOWLEDGEMENTS}

We thank Robert Simpson, of the Horticulture and Food Research Institute of New Zealand Ltd, 
for supplying us with Cry1Ba antibody and Anne Gunson, of the same institute, for giving statistical advice and conducting analyses. Bob Blair, of Auckland, New Zealand, kindly managed the apiary used in this study. This work was funded by the New Zealand Foundation for Research Science and Technology, contract No. C10X0008.

Résumé - Développement des glandes hypopharyngiennes chez des abeilles (Apis mellifera) adultes nourries avec une toxine de $B t$, une protéine liant la biotine et un inhibiteur de protéase. Afin d'étudier les effets potentiels des produits de transgènes insecticides sur le développement des glandes hypopharyngiennes, nous avons donné en nourrissement à des abeilles adultes naissantes de l'aprotinine (inhibiteur de protéase), de l'avidine (protéine liant la biotine) et de la protéine Cry1Ba (toxine $\mathrm{Bt}$ ) purifiées, puis avons mesuré leurs glandes. Nous avons aussi estimé la teneur des glandes en protéines et essayé de retrouver les produits de transgènes dans les glandes elles-mêmes. Les abeilles naissantes, de souche italienne, ont été maintenues en cages à $33^{\circ} \mathrm{C}$ et ont reçu durant 10 jours six types de nourriture pollinique : trois témoins : (i) recette de base, (ii) recette de base $+2,5 \mathrm{mg} / \mathrm{g}$ de caséine extra, (iii) mélange pollen-candy et trois autres types de nourriture constitués de la recette de base à laquelle les produits de transgènes ont été ajoutés: (i) $0,625 \mathrm{mg} / \mathrm{g}$ de Cry1Ba, (ii) $0,174 \mathrm{mg} / \mathrm{g}$ d'avidine et (iii) $2,5 \mathrm{mg} / \mathrm{g}$ d'aprotinine. Aucun des traitements n'a affecté de façon significative la survie (Fig. 1), ni le diamètre moyen des acini des glandes (Fig. 3). Les abeilles ont consommé significativement plus du mélange pollen-candy que des autres types de nourriture (Fig. 2), peut-être en raison de sa plus faible teneur en protéines et/ou sa plus forte teneur en sucres. Aucun des traitements n'a eu un effet constant et significatif sur la masse glandulaire (Fig. 4) ni sur leur teneur totale en protéines (Tab. I). Les expériences n'ont aucunement montré que l'aprotinine, l'avidine ou la toxine Cry1Ba s'étaient accumulées dans les glandes des abeilles qui les avaient reçues en nourrissement. Les résultats suggèrent qu'il est hautement improbable que l'aprotinine, l'avidine ou la toxine Cry1Ba, si elles sont présentes dans le pollen transgénique aux concentrations testées ici, aient un effet marqué sur le développement des glandes hypopharyngiennes. Néanmoins, des essais en plein champ avec des plantes transgéniques et des colonies entières d'abeilles sont nécessaires pour confirmer ces résultats.

Apis mellifera / glande hypopharyngienne / produit de transgène / protéine insecticide / toxine Bt / essai en laboratoire

Zusammenfassung - Entwicklung der Hypopharynxdrüse in adulten Bienen, die mit einem Bt Toxin, einem Biotin bindenden Protein und einem Proteasen-Hemmer gefüittert wurden. Um potentielle Effekte transgener Produkte mit Insektidwirkung auf die Entwicklung der Hypopharynxdrüse zu untersuchen, fütterten wir Aprotinin (einen Proteasen-Hemmer), Avidin (ein Biotin bindendes Protein) und Cry1Ba-Protein (ein Bt Toxin) an frischgeschlüpften adulten Honigbienen und bestimmten die Grösse ihrer Hypopharynxdrüsen. Wir bestimmten ausserdem den Proteingehalt der Drüsen und versuchten die transgenen Produkte in den Drüsen selbst nachzuweisen. Frischgeschlüpfte adulte Honigbienen (aus italienischer Abstammung) wurden bei $33{ }^{\circ} \mathrm{C}$ gekäfigt gehalten und über einen Zeitraum von zehn Tagen hinweg mit sechs verschiedenen Pollendiäten gefüttert: drei Kontrolldiäten (1) Grundrezept, (2) Grundrezept mit 2,5 mg/g Kasein-Zusatz, (3) Pollen-Zuckerteig, und drei Diäten mit Poteinzusätzen aus transgenen Quellen (1) Grundrezept mit 0,625 mg/g Cry1Ba, (2) Grundrezept mit $0,174 \mathrm{mg} / \mathrm{g}$ Avidin und (3) Grundrezept mit 2,5 mg/g Aprotinin. Keiner der Zusätze zeigte einen signifikanten Effekt auf die Lebensdauer der Bienen (Abb. 1) oder auf die Acini-Durchmesser der Drüsen (Abb. 3). Der Verzehr der Pollen-Zuckerteigmischung seitens der Bienen war signifikant höher als der der anderen Diäten (Abb. 2), vermutlich aufgund ihres niedrigeren Pollen- und höheren Zuckergehalts. Bei keiner der Diäten zeigten sich konsistent signifikante Unterschiede hinsichtlich der Drüsenmasse (Abb. 4) oder des Gesamtproteingehalts (Tab. I). In keinem der spezifischen Assays ergaben sich Anhaltspunkte für eine Anhäufung von Aprotinin, Avidin oder Cry1Ba in den Drüsen der Bienen, die diese Proteine verzehrt hatten. Diese Ergebnisse lassen darauf schliessen, dass Aprotinin, Avidin oder Cry1Ba keine nennenswerten Auswirkungen auf die Entwicklung der Hypopharynxdrüsen von Honigbienen zeigen sollten, wenn sie in transgenem Pollen in den hier untersuchten Konzentrationen vorkommen. Diese Aussagen müssen jedoch in Feldversuchen mit transgenen Pflanzen und an ganzen Völkern überprüft und bestätigt werden.

Apis mellifera / Hypopharynxdrüse / transgenes Produkt / Protein mit Insektizidwirkung / Bt Toxin / Laborversuch

\section{REFERENCES}

Ambrose J.T. (1992) Management for honey production, in: Graham J.M. (Ed.), The Hive and the Honey Bee, Hamilton, Illinois, pp. 601-655.

Anon (2000) Bt Plant-Pesticides Biopesticides Registration Action Document, United States Environmental Protection Agency, http://www.epa.gov/scipoly/ sap/2000/october/brad2_scienceassessment.pdf (accessed on 19 October 2004).

Arpaia S. (1996) Ecological impact of Bt-transgenic plants: 1. Assessing possible effects of CryIIIB 
toxin on honey bee (Apis mellifera L.) colonies, J. Genet. Breed. 50, 315-319.

Babendreier D., Kalberer N., Romeis J., Fluri P., Bigler F. (2004) Pollen consumption in honey bee larvae: a step forward in the risk assessment of transgenic plants, Apidologie 35, 293-300.

Billingsley P.F., Lehane M.J. (1996) Structure and ultrastructure of the insect midgut: in: Lehane M.J., Billingsley P.F. (Eds.), Biology of the Insect Midgut, Chapman \& Hall, London, UK, pp. 3-30.

Bonadé Bottino M., Girard C., Le Métayer M., Picard-Nizou A.L., Sandoz G., Lerin J., PhamDelègue M.H., Jouanin L. (1998) Effects of transgenic oilseed rape expressing proteinase inhibitors on pest and beneficial insects, Proc. Int. Symp. Brassicas, Acta Hort. 459, 235-239.

Brødsgaard H.F., Brødsgaard C.J., Hansen H., Lövei G.L. (2003) Environmental risk assessment of transgene products using honey bee (Apis mellifera) larvae, Apidologie 34, 139-145.

Bruins B.G., Scharloo W., Thorig G.E.W. (1991) The harmful effect of light on Drosophila is dietdependent, Insect Biochem. 21, 535-539.

Burgess E.P.J., Malone L.A., Christeller J.T. (1996) Effects of two proteinase inhibitors on the digestive enzymes and survival of honey bees (Apis mellifera), J. Insect Physiol. 42, 823-828.

Burgess E.P.J., Malone L.A., Christeller J.T., Lester M.T., Murray C., Philip B.A., Phung M.M., Tregidga E.L. (2002a) Avidin expressed in transgenic tobacco leaves confers resistance to two noctuid pests, Helicoverpa armigera and Spodoptera litura, Transgenic Res. 11, 185-198.

Burgess E.P.J., Lövei G.L., Malone L.A., Nielsen I.W., Gatehouse H.S., Christeller J.T. (2002b) Prey-mediated effects of the protease inhibitor aprotinin on the predatory carabid beetle Nebria brevicollis, J. Insect Physiol. 48, 1093-1101.

Colebatch G.M. (1999) Organisation of digestion and digestive proteinases in the green mirid, Creotiades dilutus, Ph.D Thesis, Australian National University, Canberra, $184 \mathrm{p}$.

Christeller J.T., Burgess E.P.J., Mett V., Gatehouse H.S., Markwick N.P., Murray C., Malone L.A., Wright M., Philip B.A., Watt D., Gatehouse L.N., Lovei G.L., Shannon A.L., Phung M.M., Watson L., Laing W.A. (2002) The expression of a mammalian protease inhibitor, bovine spleen trypsin inhibitor (SI), in tobacco and effects on Helicoverpa armigera larvae, Transgenic Res. 11, 161173.

Crailsheim K., Stolberg E. (1989) Influence of diet, age and colony condition upon intestinal proteolytic activity and size of the hypopharyngeal glands in the honeybee (Apis mellifera L.), J. Insect Physiol. 35, 595-602.
Crailsheim K., Hrassnigg N., Lorenz W., Lass A. (1993) Protein consumption and distribution in a honeybee colony (Apis mellifera carnica Pollm.), Apidologie 24, 509-511.

Fishman L., Zlotkin E. (1984) A diffusional route of transport of horseradish peroxidase through the midgut of the fleshfly, J. Exp. Zool. 229, 189195.

Graham J., Gordon S.C., McNicol R.J. (1997) The effect of the CpTI gene in strawberry against attack by vine weevil (Otiorhynchus sulcatus F. Coleoptera: Curculionidae), Ann. Appl. Biol. $131,133-139$.

Greenplate J. (1997) Response to reports of early damage in 1996 commercial Bt transgenic cotton (Bollgard ${ }^{\mathrm{TM}}$ ) plantings, Soc. Invertebr. Pathol. Newsletter 29, 15-18.

Hanley A.V., Huang Z.Y., Pett W.L. (2003) Effects of dietary transgenic Bt corn pollen on larvae of Apis mellifera and Galleria mellonella, J. Apicult. Res. 42, 77-81.

Hatfield P.R. (1988) Detection and localisation of antibody ingested with a mosquito blood meal, Med. Vet. Entomol. 2, 339-345.

Heath R.L., McDonald G., Christeller J.T., Lee M., Bateman K., West J., van Heeswijck R., Anderson M.A. (1997) Proteinase inhibitors from Nicotiana alata enhance plant resistance to insect pests, $\mathrm{J}$. Insect Physiol. 43, 833-842.

Hood E.E., Witcher D.R., Maddock S., Meyer T., Baszczynski C., Bailey M., Flynn P., Register J., Marshall L, Bond D., Kulisek E., Kusnadi A., Evangelista R., Nikolov Z., Wooge C., Mehigh R.J., Hernan R., Kappel W.K., Ritland D., Li C.P., Howard J.A. (1997) Commercial production of avidin from transgenic maize: characterization of transformant, production, processing, extraction and purification, Mol. Breed. 3, 291306.

Huang Z.Y., Otis G.W. (1989) Factors determining hypopharyngeal gland activity of worker honey bees (Apis mellifera L.), Insectes Soc. 36, 264 276.

Jouanin L., Girard C., Bonadé-Bottino M., Le Métayer M., Picard Nizou A.L., Lerin J., PhamDelègue M.H. (1998) Impact de colzas transgéniques exprimant des inhibiteurs de protéases sur coléoptères phytophages et sur abeilles, Cah. Agric. 7, 531-536.

Koziel M.G., Beland G.L., Bowman C., Carozzi N.B., Crenshaw R., Crossland L., Dawson J., Desai N., Hill M., Kadwell S., Launis K., Lewis K., Maddox D., McPherson K., Meghji M.R., Merlin E., Rhodes R., Warren G., Wright M., Evola S.V. (1993) Field performance of elite transgenic maize plants expressing an insecticidal protein derived from Bacillus thuringiensis, Bio/Technology 11, 194-200. 
Kramer K.J., Morgan T.D., Throne J.E., Dowell F.E., Bailey M., Howard J.A. (2000) Transgenic avidin maize is resistant to storage insect pests, Nat. Biotechnol. 18, 670-674.

Lass A., Crailsheim K. (1996) Influence of age and caging upon protein metabolism, hypopharyngeal glands and trophallactic behavior in the honey bee (Apis mellifera L.), Insectes Soc. 43, 347358.

Leplé J.C., Bonadé-Bottino M., Augustin S., Pilate G., le Tan V.D., Delplanque A., Cornu D., Jouanin L. (1995) Toxicity to Chrysomela tremulae (Coleoptera: Chrysomelidae) of transgenic poplars expressing a cysteine proteinase inhibitor, Mol. Breed. 1, 319-328.

Levinson H.Z., Levinson A.R., Offenberger M. (1992) Effect of dietary antagonists and corresponding nutrients on growth and reproduction of the flour mite (Acarus siro L), Experientia 48, 721-729.

Malone L.A., Giacon H.A., Burgess E.P.J., Maxwell J.Z., Christeller J.T., Laing W.A. (1995) Toxicity of trypsin endopeptidase inhibitors to honey bees (Hymenoptera: Apidae), J. Econ. Entomol. 88, 46-50.

Malone L.A., Burgess E.P.J., Christeller J.T., Gatehouse H.S. (1998) In vivo responses of honey bee midgut proteases to two protease inhibitors from potato, J. Insect Physiol. 44, 141-147.

Malone L.A., Burgess E.P.J., Stefanovic D. (1999) Effects of a Bacillus thuringiensis toxin, two Bacillus thuringiensis biopesticide formulations, and a soybean trypsin inhibitor on honey bee (Apis mellifera L.) survival and food consumption, Apidologie 30, 465-473.

Malone L.A., Burgess E.P.J., Gatehouse H.S., Voisey C.R., Tregidga E.L., Philip B.A. (2001) Effects of ingestion of a Bacillus thuringiensis toxin and a trypsin inhibitor on honey bee flight activity and longevity, Apidologie 32, 57-68.

Malone L.A., Pham-Delègue M.H. (2001) Effects of transgene products on honey bees (Apis mellifera) and bumblebees (Bombus sp.), Apidologie 32, 287-304.

Malone L.A., Burgess E.P.J., Mercer C.F., Christeller J.T., Lester M.T., Murray C., Phung M.M., Philip B.A., Tregidga E.L., Todd, J.H. (2002a) Effects of biotin-binding proteins on eight species of pasture invertebrates, N.Z. Plant Prot. 55, 411-415.

Malone L.A., Tregidga E.L., Todd J.H., Burgess E.P.J., Philip B.A., Markwick N.P., Poulton J., Christeller J.T., Lester M.T. Gatehouse H.S. (2002b) Effects of ingestion of a biotin-binding protein on adult and larval honey bees, Apidologie $33,447-458$.

Markwick N.P., Docherty L.C., Phung M.M., Lester M.T., Murray C., Yao J.-L., Mitra D.S., Cohen D., Beuning L.L., Kutty-Amma S., Christeller
J.T. (2003) Transgenic tobacco and apple plants expressing biotin-binding proteins are resistant to two cosmopolitan insect pests, potato tuber moth and lightbrown apple moth, respectively, Transgenic Res. 12, 671-681

Murray C., Sutherland P.W., Phung M.M., Lester M.T., Marshall R.K., Christeller J.T. (2002) Expression of biotin-binding proteins, avidin and streptavidin, in plant tissues using plant vacuolar targeting sequences, Transgenic Res. 11, 199214.

Naiem E.S., Hrassnigg N., Crailsheim K. (1999) Nurse bees support the physiological development of young bees (Apis mellifera L.), J. Comp. Physiol. B 169, 271-279.

Pham-Delègue M.H., Girard C., Le Métayer M., Picard-Nizou A.L., Hennequet C., Pons O., Jouanin L. (2000) Long-term effects of soybean protease inhibitors on digestive enzymes, survival and learning abilities of honeybees, Entomol. Exp. Appl. 95, 21-29.

Picard-Nizou A.L., Grison R., Olsen L., Pioche C., Arnold G., Pham-Delègue M.H. (1997) Impact on proteins used in plant genetic engineering toxicity and behavioral study in the honeybee, J. Econ. Entomol. 90, 1710-1716.

Sandoz G. (1996) Étude des effets d'inhibiteurs de protéases sur un insecte pollinisateur, l'abeille domestique Apis mellifera L., Institut National Agronomique Paris-Grignon, Diplôme d'Agronomie Approfondie thesis, 1996.

Schur A., Tornier I., Neumann C. (2000) Bt-Mais und non Bt-Mais: vergleichende Untersuchungen an Honigbienen (Tunnelzeltversuch), Apidologie 31, 616-617.

Simpson R.M., Burgess E.P.J., Markwick N.P. (1997) Bacillus thuringiensis d-endotoxin binding sites in two Lepidoptera, Wiseana spp. and Epiphyas postvittana, J. Invertebr. Pathol. 70, 136-42.

Sims S.R. (1995) Bacillus thuringiensis var. kurstaki (CryIA(c)) protein expressed in transgenic cotton: Effects on beneficial and other non-target insects, Southwest. Entomol. 20, 493-500.

Stanley-Horn D.E., Dively G.P., Hellmich R.L., Mattila H.R., Sears M.K., Rose R., Jesse L.C.H., Losey J.E., Obrycki J.J., Lewis L. (2001) Assessing the impact of Cry1Ab-expressing corn pollen on monarch butterfly larvae in field studies, Proc. Natl. Acad. Sci. (USA) 98, 11931-11936.

Suzuki K. (1988) The development of hypopharyngeal glands in honey bee workers, Bull. Fac. Education, Chiba University 36, pp. 93-101.

Vaughan J.A., Wirtz R.A., do Rosario V.E., Azad A.F. (1990) Quantitation of antisporozoite immunoglobulins in the hemolymph of Anopheles stephensi after bloodfeeding, Am. J. Trop. Med. Hyg. 42, 10-16. 